\title{
Factors Affecting Customer Loyalty of Using Internet Banking in Malaysia
}

\author{
Beh Yin Yee and T.M. Faziharudean \\ Faculty of Business and Accountancy, University of Malaya, Kuala Lumpur, Malaysia,
}

\begin{abstract}
Internet banking (IB) has become one of the widely used banking services among Malaysian retail banking customers in recent years. Despite its attractiveness, customer loyalty towards Internet banking website has become an issue due to stiff competition among the banks in Malaysia. As the development and validation of a customer loyalty model in Internet banking website context in Malaysia had not been addressed by past studies, this study attempts to develop a model based on the usage of Information System, with the purpose to investigate factors influencing customer loyalty towards Internet banking websites. A questionnaire survey was conducted with the sample consisting of Internet banking users in Malaysia. Factors that influence customer loyalty towards Internet banking website in Malaysia have been investigated and tested. The study also attempts to identify the most essential factors among those investigated: service quality, perceived value, trust, habit and reputation of the bank.

Based on the findings, trust, habit and reputation are found to have a significant influence on customer loyalty towards individual Internet banking websites in Malaysia. As compared to trust or habit factors, reputation is the strongest influence. The results also indicated that service quality and perceived value are not significantly related to customer loyalty. Service quality is found to be an important factor in influencing the adoption of the technology, but did not have a significant influence in retention of customers. The findings have provided an insight to the internet banking providers on the areas to be focused on in retaining their customers.
\end{abstract}

Keywords: Internet banking, banking website, customer loyalty, reputation

\section{Introduction}

Internet banking (IB) refers to the banking services provided via a secure website operated by the bank provider, thus facilitating the use of the Internet as a remote delivery channel. Internet banking allows bank customers with appropriate access to manage their finances with minimal inconvenience as it provides a fast and convenient way to undertake various banking transactions via the Internet banking website from home, office or elsewhere, 24 hours a day, 7 days a week. In Malaysia, Internet banking services have been operational since the year 2000 . Currently, only banking institutions licensed under the Banking and Financial Institution
Act 1989 (BAFIA) and the Islamic Banking Act 1983 are allowed to offer Internet banking services here. Table 1 provides a list of banks in Malaysia that now offer an Internet banking service.

In 2002 about 25,000 Maybank customers and 10,000 HSBC customers subscribed to Internet banking in Malaysia (Yu, 2002; Bernama, 2002). By 2008 there were over 4.5 million registered Internet banking customers in Malaysia in, which accounts for $85.5 \%$ of the total adult Internet user population. Internet banking has a yearly growth rate of $40.6 \%$ compared to the previous year that shows it is both growing

Copyright (C) 2010 Beh Yin Yee and Dr T.M. Faziharudean. This is an open access article distributed under the Creative Commons Attribution License unported 3.0, which permits unrestricted use, distribution, and reproduction in any medium, provided that original work is properly cited. Contact author: Beh Yin Yee, email: vlrbeh@hotmail.com 
popularity and rapidly becoming one of the most popular services utilized by Malaysian retail banking customers. Internet banking providers are working ceaselessly to add to or improve their Internet banking services in order to make their bank a better choice prospective customer and to retain existing ones.

Table 1: List of Internet Banking in Malaysia by Banking Providers

\begin{tabular}{|l|l|}
\hline Bank Name & Internet Banking (IB) \\
\hline Al Rahji Bank & Al Rahji Bank IB \\
\hline Affin Bank & affinOnline.com \\
\hline Alliance Bank & Alliance Online \\
\hline AmBank & AmOnline \\
\hline CIMB Bank & CIMB Clicks \\
\hline Citibank & Citibank Online \\
\hline EON Bank & EON Bank IB \\
\hline Hong Leong Bank & Hong Leong Online \\
\hline HSBC Bank & Online@HSBC \\
\hline Malayan Banking & Maybank2u.com \\
\hline OCBC Bank & OCBC IB \\
\hline Public Bank & PBeBank.com \\
\hline RHB Bank & RHB Bank IB \\
\hline Standard Chartered Bank & Standard Chartered Online \\
\hline The Royal Bank of Scotland & RBS Access Online \\
\hline United Overseas Bank & UOB IB \\
\hline
\end{tabular}

(Source: Bank Negara Malaysia)

Malaysia is expected to see further global growth and expansion in Internet banking (Ayny, 2008). Despite Internet banking's attractiveness, website loyalty among Internet banking consumers has become an issue as there are many competing Internet banking website offerings in the Malaysian market. This is of concern to banks because customer loyalty is important in that it has a positive effect on long-term profitability (Ribbink et al., 2004). According to Reichheld et al. (2000) and Reichheld and Schefter (2000) the high costs of acquiring new e-customers can lead to unprofitable relationships with new customers for up to three years. As a consequence, it is crucial for online companies to create and maintain a loyal customer base, and to monitor the profitability of each customer segment (Reinartz and Kumar, 2002). Furthermore, new channels for online communication offer a host of new and promising opportunities for customer retention, while at the same time intensifying competition (Vatanasombut et al., 2004). However, few companies seem to succeed in creating eloyalty, and little is known about the mechanisms involved in generating customer loyalty on the Internet (Ribbink et al., 2004). In the online environment the cost of obtaining and retaining a customer is usually higher than through traditional channels (Reichheld and Schefter, 2000) and the customer's loyalty is relatively lower, as customers are more interested in conviniences and ease of use when using Internet banking (Turban et al., 2000). While there is a rich body of literature on online financial services and their adoption, little is known about how to keep customers loyal to an online bank (Floh and Treiblmaie, 2006), This applies to Malaysia as well as to other countries and therefore suggests a crucial need for research into which factors are responsible for keeping customers loyal in Internet banking environment.

Given that relevant research on loyalty in the Internet banking context is limited, the purpose of this study is to investigate the level of customer loyalty to Internet banking websites in Malaysia with the following research questions being addressed:

1. What factors determine the loyalty of existing customers towards Internet 
banking services among the consumers in Malaysia?

2. Which factors are essential in forming loyalty among Malaysian consumers in the Internet banking environment?

\section{Literature Review}

Previous studies that have investigated the issues of customer retention and customer loyalty, including e-services, have related the issues to the following factors:

\section{Service Quality}

Service quality has become an issue that businesses have focused up on with eservices that enable electronic communication, information gathering, transaction processing and data interchange between online vendors and customers across time and space (Featherman and Pavlou, 2002). In online environments, service quality is defined as the extent to which a website facilitates efficient and effective shopping, purchasing, and delivery of product and services (Zeithaml et al., 2002). Santos (2003) described e-service quality in terms of overall customer evaluations and judgments regarding the excellence and the quality of e-service delivery in the virtual marketplace.

A study by Parasuraman et al. (2005) on the Internet service quality of online shopping websites resulted in the development of a service quality scale, the e-SQ scale, consisting of seven dimensions: efficiency, system availability, fulfilment, privacy, responsiveness, compensation and contact. It is slightly different from the e-SQ scale developed by Zeithaml et al. (2001) which has 11 dimensions: reliability, responsibility, access, flexibility, and ease of navigation, efficiency, assurance, security, price knowledge, site aesthetics and customization / personalization.

Furthermore, a study by Ribbink et al. (2004) in an e-commerce context (online book and CD stores) the service quality dimensions consisted of: ease of use, escape, responsiveness and customization. Cristobal et al. (2007) further developed a service quality scale which consists of multidimensional constructs of web design, customer service, assurance and order management.

\section{Perceived Value}

Delivering superior customer value is an essential strategy for firms to gain competitive advantage and long term success (Parasuraman, 1997; Woodruff, 1997). Various researchers have defined perceived value as the customer's overall assessment of the benefits they receive relative to the sacrifice they make (Dodds et al., 1991; Slater, 1997; Woodruff, 1997). According to Parasuraman and Grewal (2000), there are four distinct types of perceived value in their proposed expanded model of customer loyalty: (1) acquisition value, (2) transaction value, (3) in-use value, and (4) redemption value. Perceived value is implied as a dynamic construct and may change its central component(s) over time. For instance, acquisition and transaction value may be dominant during and immediately after a purchase, while inuse and redemption value may emerge only during later stages of using the product/service. According to Lin and Wang (2006), in their study on the determinants of customer loyalty in mobile commerce contexts, the benefit components of perceived value include intrinsic attributes (ie how a purchase makes one feel), extrinsic attributes (ie reputation of the product/service), perceived quality and other relevant high level abstractions. The 'sacrifice' components of perceived value include: monetary prices and nonmonetary costs (eg time, energy, effort).

\section{Trust}

Based on previous research, trust has been defined as: (1) a set of specific beliefs dealing primarily with the integrity, benevolence, and ability of another party (Doney and Cannon, 1997; Gefen and Silver, 1999); (2) a general belief that another party can be trusted (Gefen, 2000; Hosmer, 1995; Moorman et al., 1992), sometimes also called trusting intentions (McKnight et al., 1998) or the willingness of a party to be vulnerable to the actions of another (Mayer et al., 1995); (3) affect reflected in "feelings" of confidence and security in the caring 
response of the other party (Rempel et al., 1985). Some researchers have combined the first two conceptualizations into one construct (Doney and Cannon, 1997). Other researchers have split the first two conceptualizations, declaring the specific beliefs as antecedents of the general belief (Jarvenpaa and Tractinsky, 1999; Mayer and Davis, 1999; Mayer et al. 1995).

Despite the existence of different definition of trust in previous literature, Gefen et al. (2003) adopted the conceptualization of trust as a set of specific beliefs which includes integrity, benevolence, ability and predictability to be applied in e-commerce, and specifically in the online shopping context. The definition is aligned with the past literature where it has been most widely used in studies related to ongoing economic relationships that deal with buyer-seller and business interactions (Crosby et al. 1990; Doney and Cannon 1997; Ganesan 1994; Gefen 2002; Jarvenpaa et al. 2000). Lin and Wang (2006) who conducted their study in an m-commerce context have adopted the same view by defining trust as a set of specific beliefs dealing primarily with the integrity (trustee honesty and promise keeping), benevolence (trustee caring and motivation to act in the truster's interest), competence (ability of trustee to do what the truster's needs) and predictability (trustee's behavioral consistency) of a particular m-vendor. The definition of trust as a specific set of beliefs is adopted in this study as the Internet banking website context is a part of ecommerce which deals with buyer-seller and business transactions.

\section{Habit}

The role of habit in predicting behavior has been verified in previous studies (Gefen, 2003, Ouellette \& Wood, 1998; Trafimow, 2000). Most habitual behavior arises and proceeds efficiently, effortlessly, and unconsciously (Aarts et al., 1998) and habit can predict customers future behavior (Bamberg, Ajzen, \& Schmidt, 2003). Gefen (2003) defined habit is what an individual usually does when there is a behavioral preference in the present. Habitual behavior leads to the continuation of the same type of behavior (Aarts et al., 1998; Gefen, 2003). This is aligned with Ouellette and Wood (1998) who stated that once a behavior has become a habit or well-practised behavior, it becomes automatic and is carried out without conscious decision. This implies that habit is guided by automated cognitive processes, rather than by elaborate decision making processes. In Internet banking, the acquire skill to use a particular website resulting in habit. It will discourage switching to use other websites that require new skill and familiarity.

\section{Reputation}

Herbig and Milewicz (1993) have defined reputation as an estimation of the consistency over time of an attribute of an entity. An organization can therefore have numerous reputations (ie price, product quality and innovativeness reputations) and/or global reputation. According to Casalo et al. (2008), reputation must be understood as referring not only to the website, but also the entire organization. The website is simply the main communication channel between consumer and organization. Thus, this study considers a holistic perspective of reputation, not limited to online services that the banks are offering to their customers.

\section{Customer Loyalty}

Many studies have acknowledged the importance of loyalty in the electronic context and have analyzed this aspect in detail (Lynch et al., 2001; Reichheld et al., 2000; Srinivasan et al., 2002; Reichheld and Schefter, 2000). Customer loyalty has been defined as a deeply held commitment to repurchase or re-patronize a preferred product/service consistently in the future, thereby causing repetitive same-brand or same brand-set purchasing, despite situational influences and marketing efforts having the potential to cause switching behavior (Oliver, 1999). Subsequently Ribbink et al. (2004) stated that this general definition applies to online loyalty as well.

Ranaweera et al. (2003) explained that loyalty consists of both behavioral and attitudinal dimensions - more specifically: 
purchase intentions (Boulding et al., 1993), word of mouth (Gremler et al., 2001) and commitment (Moorman et al., 1992) dimensions. Purchase intentions were defined as the propensity to purchase a product or service at some point in the future (Ranaweera et al., 2003). Customer commitment refers to the strength of relational ties and to the desire to maintain a relationship (Bansal et al., 2003). Word of mouth is defined as oral, person to person communication between a communicator and a receiver whom the receiver perceives as non-commercial with respect to a brand, product or service (Arndt, 1967).

The relationships between the previously described factors with respect to customer loyalty are further expanded upon in the following paragraphs.

Relationship between Service Quality and Customer Loyalty

Zahorik and Rust (1992) argued that modeling perceived quality as an influencing factor of customer loyalty will provide significant diagnostic ability to any framework that includes customer loyalty as a dependent construct. Previous research has also confirmed that a relationship between perceived quality and customer loyalty both exists and is positive (Anderson and Sullivan, 1993; Cronin and Taylor, 1992; Harrison-Walker, 2001). According to Zeithaml et al. (1996), the existence of a relationship between service quality and customer retention at a higher level indicates that service quality has an impact on individual consumer behavior, where superior service quality leads to favorable behavioral intentions (ie customer loyalty), while unfavorable behavioral intentions are a consequence of inferior service quality. Ruyter and Wetzels (1998) further posited the importance of determining the nature and strength of the relationship between perceived service quality and loyalty for a firm and/or different industry levels.

However, according to Manhaimer (2007), consumer loyalty is not significantly influenced by perceived product quality in retail industry for product with low levels of involvement, and the purchase decision is influence by other factors. This study concluded that perceived product quality is not a predicting factor of customer loyalty; it is possible for consumers to be loyal to different products with different qualities according to their needs and economic ability. Nevertheless, the author also stated that high perceived quality may lead to loyalty if it involves high product involvement. Meanwhile, Cristobal et al. (2007) rejected the hypothesis that higher levels of perceived quality in web site services foster higher levels of web site loyalty as the findings show that perceived service quality does not has a significant effect on loyalty.

Relationship between Perceived Value and Customer Loyalty

Past literature showed that perceived value contributed to customer loyalty (Dodds et al., 1991; Grewal et al., 1998; Voss et al., 1998). Chen and Dubinsky (2003) established a conceptual framework of perceived value in a $\mathrm{B} 2 \mathrm{C}$ e-commerce setting for elaborating the relationship between perceived value and key determinants. The model supports the definite importance of perceived value in determining a consumer's online purchase intention (an aspect of customer loyalty). Anderson and Srinivasan (2003) also suggested that when perceived value was low customers would be more inclined to switch to competing products in order to increase perceived value, thus a decline in loyalty. However, an investigation of perceived value as a predictor of customer loyalty in the golf traveller market by Petrick and Backman (2002) found it not to be predictive. Furthermore, a finding from the study by Omar et al. (2007) showed that perceived value was not a predictor of customer store loyalty in a retail market context.

Relationship between Trust and Customer Loyalty

Trust is expected to affect customers' willingness to purchase online; online customers generally stay away from electronic vendors whom they do not trust (Jarvenpaa and Tractinsky, 1999; Reichheld 
and Schefter, 2000). Conversely, Chiou (2004) found that perceived trust had direct and positive impacts upon the loyalty of customers. This was supported by a study by Corbitt et al. (2003) on online firms which demonstrated there is a strong positive effect of trust on loyalty. Moreover, Ribbink et al. (2004) investigated the role of customer evaluations of electronic service and e-trust in explaining customer loyalty to online retailers. The findings showed that etrust directly and positively affects e-loyalty. Additionally, Lee and Turban (2001) predicted that lack of trust is frequently cited as a reason for not purchasing from online merchants. Although most of the literature showed a positive impact of trust on loyalty, Finn and Kayande (1997) found that in an online environment, trust is not considered as a major contributor to loyalty.

Relationship between Habit and Customer Loyalty

About 40-60\% of customers' repeat purchase from the same store through force of habit (Beatty and Smith, 1987). Trafimow (2000) and Verplanken et al. (1998) highlighted that habit can directly affect behavioral intentions more than do attitude and social norms. Gefen (2003) found that habit alone can explain a large proportion of the variance in the continued use of a website. The finding suggested that customers' intentions of repeat purchases on a specific website (one they have habitually used in the past), will increase, due directly to the reinforcement of the habit of visiting that specific website. In the research done by Lin and Wang (2006), they claimed that customers visit websites out of habit, rather than through a conscious evaluation of the perceived benefits and costs entailed. When habit is wellentrenched, people tend to ignore external information or rational strategy. Such an effect is a central element in Triandis' (1971) theory of attitude and attitude change, in which behavioral intentions are the product of attitude, social norms and affect caused by habit. They concluded that habitual prior preferences in the use of specific m-commerce systems directly and strongly increased a consumer's intention to continue using the same systems.

\section{Relationship between Reputation and Customer Loyalty}

A more positive reputation tends to develop sales and market share (Shapiro, 1982) and to establish greater customer loyalty (Andreassen and Lindestad, 1998; Robertson, 1993). When comparing on- and offline exchange, Standifird et al. (1999) argued that the reputation of online suppliers are significantly more important to online consumers than any offline context (even catalog shopping). Eastlick and Feinberg (1999) argued that the behavioral intentions of catalog shopping customers (ie customer loyalty) as compared to "conventional" brick-and-mortar shoppers are more influenced by the reputation of the organization, since such a medium of exchange requires consumers to purchase without immediate delivery or tangible exchange. Resnick and Zeckhauser (2002) further suggested that the best-known service companies with good reputations such as eBay and Google are the ones with healthiest profits and a loyal client base.

\section{Research Methodology}

\section{Research Model}

Based on the literature review, a conceptual model was developed which consisted of the determinants of customer loyalty as the independent variables (IV), and of customers' loyalty behavior as the dependent variable (DV). The model focused on the factors influencing customer loyalty which consists of the relationship of service quality, perceived value, trust, habit and reputation with respect to customer loyalty towards Internet banking websites. The model is summarized in Figure 1. 


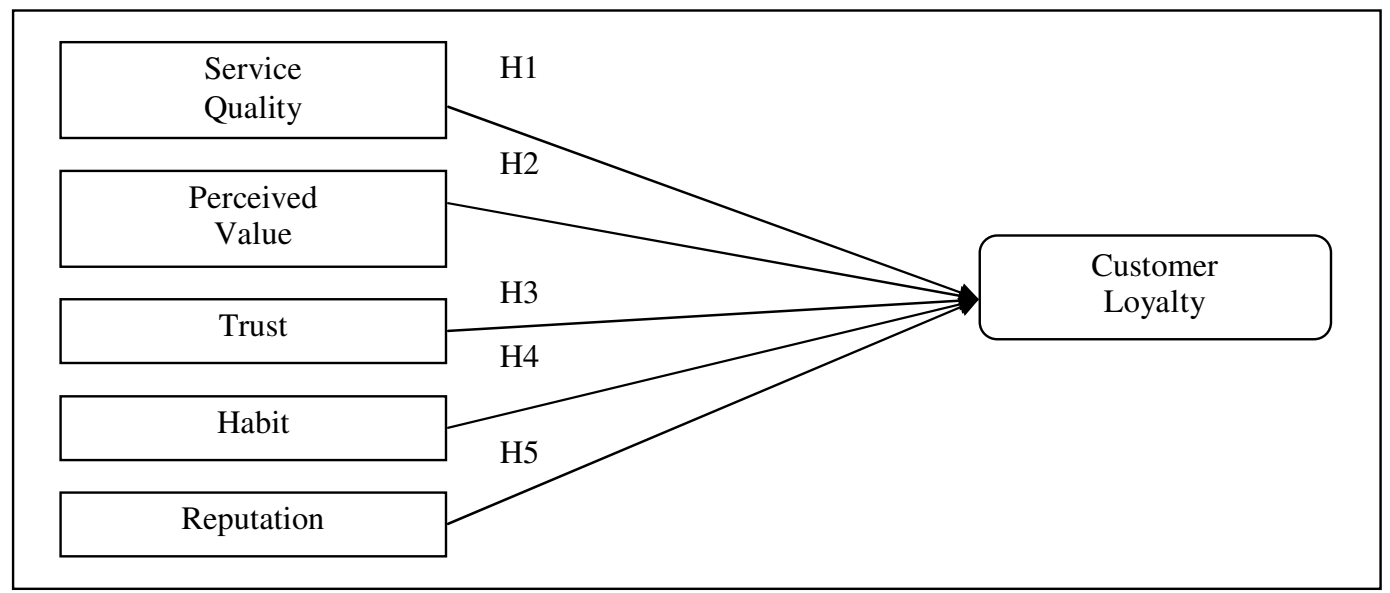

Fig 1. Conceptual Framework

\section{Research Hypotheses}

As discussed in the literature review, service quality is described as the overall customer evaluations and judgments regarding the excellence and the quality of e-service delivery in the virtual marketplace (Santos, 2003) and is related to web design, customer service, assurance and order management dimensions (Cristobal et al., 2007). Dean (2002) in his study on the contribution of service quality of call centres to customer loyalty to the providing organization in Australia has found that perceived service quality is positively related to customer loyalty. Meanwhile, Wolfinbarger and Gilly (2002) showed that perceived quality is the second most important predictor of loyalty and intention to repeat a purchase. Flavian et al. (2006) suggested aspects such as how user-friendly the web site is (a part of the service quality) are determinants of web site loyalty levels. As a consequence, the first hypothesis is stated as follows:

H1: Service quality has a positive influence on customer loyalty towards Internet banking websites.

Referring to the literature review, perceived value is related to the overall evaluation of the customer on the differences between the benefits they received and the sacrifice they make (Woodruff, 1997). In the study conducted by Lin and Wang (2006) on mcommerce, perceived value is a significant predictor of customer loyalty. To discourage customers from switching to competitors, a company must continuously work at enhancing perceived value in order to obtain higher customer loyalty. The significant relationship between perceived value and loyalty is also supported by other researchers such as Hsu (2007) and Anderson and Srinivasan (2003) as mentioned in the previous section. Therefore, a second hypothesis is proposed:

H2: Perceived value has a positive influence on customer loyalty towards Internet banking websites.

Trust, as previously discussed, refers to the consumer beliefs about certain characteristics of the supplier (primarily regarding integrity, benevolence, competence and predictability) (Gefen et al., 2003). As described in the literature review, it shows that there is an effect of trust on customer loyalty. Lin and Wang (2006) also proved that trust has a positive effect on customer loyalty in m-commerce. Customers who cannot trust an m-vendor will not be loyal to that m-vendor, even though they are satisfied with the product/services provided. When investigating e-loyalty within an e-services context, Cyr et al. (2007) showed that higher levels of trust will result in higher loyalty towards e-services website. Lastly, Floh and Treiblmaier (2006) investigated the importance of antecedents of online loyalty such as trust, quality of the Web site, 
quality of the service and overall satisfaction in the online banking environment. They found out that trust can be seen as a major antecedent of customer loyalty. In light of the above research, the third hypothesis is proposed as below:

H3: Customer trust has a positive influence on customer loyalty towards Internet banking websites.

Habit is what one usually does, that is it is a behavioral preference in the present and leads to the perpetuation of the same type of behavior (Aarts et al., 1998; Gefen, 2003). Based on the literature described in Section 2 , past studies by researchers such as Lin and Wang (2006) and Gefen (2003) have highlighted that habit directly influences loyalty. As an addition to the existing literatures in this study, Liao et al (2006) described that habitual activity with a web site will positively affect a user's intention to continue using that web site. That author also verified that a consumer's habits were a major predictor of loyalty. Following the statement mentioned above, the forth hypothesis is presented as below:

H4: Customer habit has a positive influence on customer loyalty towards Internet banking websites.

The literature review discussed that reputation relates to consistency over time of an attribute of an organization such as reputation in term of price, product quality, innovativeness, or global reputation (Herbig and Milewicz, 1993). In the study conducted by Casalo et al. (2008), a more favourable website reputation led to a greater degree of loyalty. Goode and Harris (2007) also described that favorable interpretations of the online reputation of an online supplier are directly and positively associated with the behavioral intentions of consumers such as loyalty. It showed that online consumers are tend to be extremely cautious, distrust "new" online suppliers and use perceptions of "reputation" as proxies for trustworthiness. Other literature previously mentioned also supports the relationship between reputation and loyalty. As a consequence, the fifth hypothesis is stated as follows:
H5: Reputation has a positive influence on customer loyalty towards Internet banking websites.

Questionnaire Design and Construct Measurement

A Structured questionnaire was developed to obtain the responses from Internet banking users about their opinions on various research variables. The questionnaire of this study consists of seven variables: service quality (17 items), perceived value (3 items), trust (5 items), habit (4 items), reputation (4 items) and customer loyalty (5 items). The seven variables mentioned above are used in current research with the measurement items are totally adapted based on the previous researches. The measurement items are then rephrased so that all items can be applied to Internet banking context.

In order to measure Internet banking users' perceptions of service quality, this study adapted 17 questionnaire items from the Perceived e-Service Quality (PeSQ) scale which was developed for a study done by Cristobal et al. (2007). These 17 measurement items are grouped into four dimensions: (1) web design, which is related to the design of the web site (eg content layout, content updating and userfriendliness); (2) customer service, which is related to service performance, customer sensitivity (willingness to help customers), personalised service and fast response to complaints; (3) assurance, which is related to security, privacy and reliability elements; (4) order management, which relates to the possibility of modifying and/or postponing the purchasing process at any given moment and with no obligation, and of obtaining information on product availability at the moment of purchase. Then, perceived value, trust and habit are adapted from Lin and Wang (2006), with each consisting of 3,5 and 4 items measurement respectively. Lastly, to measure customer assessment of Internet banking website provider reputation in determining their choices of Internet banking website, this study adapted a past study from Casalo et al. (2008) which consists of 4 items measurement. As for 
customer loyalty, the construct is operationalized into a total of 5 items which are adapted from the research of Lin and Wang (2006). All items were measured by seven-point Likert scales ranging from strongly disagree $(=1)$ to strongly agree $(=7)$ and respondents were asked to indicate their level of agreement with respect to each item. Respondents were also required to indicate their usage of Internet banking websites and provide demographic information.

\section{Sampling}

The sampling procedure that was adopted in this study for data collection was a convenience sampling method through questionnaire survey with a pre-planned sample size of 350 respondents. The target sample in this study was experienced Internet banking users. The questionnaire survey was distributed in Klang Valley, which is the most populous, urbanized and industrialized region in Malaysia with a total population of 6.7 million in 2005 (Dali, 2008). Overall, from the total of 350 questionnaires distributed during a one month data collection period, there were only 289 valid questionnaires received that could be used for further analysis, with a response rate of $82.57 \%$. This response rate is still adequate when compare to other similar studies which have involved sample sizes of 461 (Cristobal et al., 2007), 335 (Casalo et al., 2008), 255 (Lin and Wang, 2006).

\section{Data Analysis and Findings}

\section{Pre-Analysis Data Screening}

The regression assumption test indicated that linearity and homoscedasticity are ensured and multicollinearity, autocorrelation and multivariate outliers do not exist. Therefore, the data used in this study is fit for further statistical analysis.

\section{Reliability and Validity Test}

All items shows strong internal consistency its constructs indicated by values of Cronbach's alpha higher than 0.70 as suggested by Hair et al. (1998). This suggests that the items concerned adequately measure a single construct for each tested variable (service quality, perceived value, trust, habit, reputation and customer loyalty). Reliability measurements for each construct are shown in Table 2.

Table 2: Reliability Measurement

\begin{tabular}{|l|l|l|}
\hline Variable & $\begin{array}{l}\text { Number of items } \\
(\mathbf{N})\end{array}$ & Cronbach's Alpha \\
\hline Service Quality & 17 & .912 \\
\hline Perceived Value & 3 & .770 \\
\hline Trust & 5 & .820 \\
\hline Habit & 4 & .741 \\
\hline Reputation & 4 & .884 \\
\hline Customer Loyalty & 5 & .847 \\
\hline
\end{tabular}

For construct validity in term of the discriminant validity test, correlation analysis between the variables was performed. The result shows that correlations are low, with values no higher than 0.8, as proposed by Bagozzi (1994). This indicates that the constructs are distinct from one another and is deemed to be at an acceptable level of discrimination. Consequently content validity is also established. Table 3 shows the analysis of correlation between the variables.
For construct validity in term of convergent validity, confirmatory factor analysis was performed. KMO and Bartlett's test, as well as factor loadings for each measurement item, were examined. Based on Table 4, all measurement items of each construct are significant at level 0.01 , as suggested by Sanzo et al. (2003) and the KMO index is more than 0.6 , as suggested by Pallant (2001). Moreover, based on Table 5, most of the individual factor loadings are more than 0.50 , as recommended by Sanzo et al. 
(2003), except for item SQ16, for which it is 0.488 . However, SQ16 factor loading is close to 0.50 and the KMO and Bartlett's test showed satisfying result. Therefore item SQ16 is deemed as a valid item within the Service Quality variable. Overall, these results confirm that the measurement items of the same construct are highly correlated. In conclusion, based on the discriminant and convergent validity test, construct validity has been achieved in this study.

In general, the measurement scales used in this study are broadly valid and reliable, which permits further assessment of the relationships between the independent variables (service quality, perceived value, trust, habit, reputation) and the dependent variable (customer loyalty).

Table 3: Pearson's Correlation Coefficient between the Research Variables

\begin{tabular}{|l|l|l|l|l|l|l|}
\hline Variables & $\begin{array}{l}\text { Servic } \\
\mathbf{e} \\
\text { Qualit } \\
\mathbf{y}\end{array}$ & $\begin{array}{l}\text { Perceiv } \\
\text { ed } \\
\text { Value }\end{array}$ & Trust & Habit & $\begin{array}{l}\text { Reputatio } \\
\mathbf{n}\end{array}$ & $\begin{array}{l}\text { Customer } \\
\text { Loyalty }\end{array}$ \\
\hline Service Quality & 1 & .551 & .626 & .515 & .691 & .492 \\
\hline Perceived Value & .551 & 1 & .572 & .381 & .524 & .439 \\
\hline Trust & .626 & .572 & 1 & .467 & .545 & .563 \\
\hline Habit & .515 & .381 & .467 & 1 & .483 & .522 \\
\hline Reputation & .691 & .524 & .545 & .483 & 1 & .591 \\
\hline $\begin{array}{l}\text { Customer } \\
\text { Loyalty }\end{array}$ & .492 & .439 & .563 & .522 & .591 & 1 \\
\hline
\end{tabular}

Table 4: KMO and Bartlett's Test of Sphericity of Research Variables

\begin{tabular}{|l|l|l|l|l|}
\hline \multirow{2}{*}{ Variable } & \multirow{2}{*}{ KMO } & \multicolumn{3}{l|}{ Bartlett's Test of Sphericity } \\
\cline { 3 - 5 } & & Chi-Square & df & p-value* \\
\hline Service Quality & .923 & 2169.811 & 136 & 0.000 \\
\hline Perceived Value & .659 & 276.178 & 3 & 0.000 \\
\hline Trust & .811 & 479.653 & 10 & 0.000 \\
\hline Habit & .761 & 241.356 & 6 & 0.000 \\
\hline Reputation & .826 & 630.650 & 6 & 0.000 \\
\hline Customer Loyalty & .769 & 688.360 & 10 & 0.000 \\
\hline
\end{tabular}

Note: * Indicates significant at the $p<0.010$ level

Table 5: Factor Loadings and Measures of Research Variables

\begin{tabular}{|l|l|l|}
\hline $\begin{array}{l}\text { Variabl } \\
\text { e }\end{array}$ & Measure & $\begin{array}{l}\text { Factor } \\
\text { Loadin } \\
\text { g }\end{array}$ \\
\hline Service Quality & .554 \\
\hline SQ1 & Products/services and its features are correctly presented & .597 \\
\hline SQ2 & Website information is regularly updated & .646 \\
\hline SQ3 & Website pages load quickly & .689 \\
\hline SQ4 & The contents are easily found in the web site (ease of navigation) & .720 \\
\hline SQ5 & Full information on product features and services offered & .674 \\
\hline SQ6 & $\begin{array}{l}\text { When promise to do something within a certain timescale, it is } \\
\text { done }\end{array}$ & .700 \\
\hline SQ7 & $\begin{array}{l}\text { When customer has a complaint or grievance, it is dealt with } \\
\text { rapidly and effectively }\end{array}$ \\
\hline \multicolumn{2}{|l}{ (continued) }
\end{tabular}


Table 5 continued

\begin{tabular}{|c|c|c|}
\hline $\begin{array}{l}\text { Variabl } \\
\text { e }\end{array}$ & Measure & $\begin{array}{l}\text { Factor } \\
\text { Loading }\end{array}$ \\
\hline SQ8 & The service is performed properly first time & .638 \\
\hline SQ9 & The provider provides its customers with a tailor-made service & .564 \\
\hline SQ10 & $\begin{array}{l}\text { The stated delivery period is adhered to, at the time of delivery } \\
\text { agreed on }\end{array}$ & .656 \\
\hline SQ11 & $\begin{array}{l}\text { An image of reliability and trustworthiness in one's transactions is } \\
\text { transmitted }\end{array}$ & .689 \\
\hline SQ12 & The confidentiality of customer data is ensured & .689 \\
\hline SQ13 & $\begin{array}{l}\text { The operation carried out satisfactorily once the customer has } \\
\text { confirmed the transaction }\end{array}$ & .750 \\
\hline SQ14 & $\begin{array}{l}\text { Clear information is provided on how to make the } \\
\text { purchase/transaction }\end{array}$ & .711 \\
\hline SQ15 & $\begin{array}{l}\text { Security elements are incorporated in the website, and customer is } \\
\text { made aware of these }\end{array}$ & .690 \\
\hline SQ16 & $\begin{array}{l}\text { Customer can opt to modify and/or defer at any time the transaction } \\
\text { process without commitment }\end{array}$ & .488 \\
\hline SQ17 & $\begin{array}{l}\begin{array}{l}\text { Contains information on product availability } \\
\text { dealing/transacting }\end{array} \\
\end{array}$ & .616 \\
\hline \multicolumn{3}{|c|}{ Perceived Value } \\
\hline PV1 & Product/service is good value for money & .896 \\
\hline PV2 & Price/fee charges are acceptable & .818 \\
\hline PV3 & Product/service is considered to be a good deal/buy & .803 \\
\hline \multicolumn{3}{|l|}{ Trust } \\
\hline TR1 & Based on my experience in the past, I know it is honest & .781 \\
\hline TR2 & Based on my experience in the past, I know it cares about customers & .784 \\
\hline TR3 & Based on my experience in the past, I know it is not opportunistic & .742 \\
\hline TR4 & Based on my experience in the past, I know it is predictable & .749 \\
\hline TR5 & Based on my experience in the past, I know it knows its market & .773 \\
\hline \multicolumn{3}{|l|}{ Habit } \\
\hline HB1 & $\begin{array}{l}\text { This website is where I usually go to buy/use banking } \\
\text { products/services through the Internet }\end{array}$ & .765 \\
\hline HB2 & This is my preferred website providing banking products/services & .746 \\
\hline HB3 & $\begin{array}{l}\text { When I need to buy/use banking products/services through the } \\
\text { Internet, this is the first website I try }\end{array}$ & .750 \\
\hline HB4 & I often buy/use the banking products/services from this website & .751 \\
\hline HB1 & Based on my experience in the past, I know it knows its market & .773 \\
\hline \multicolumn{3}{|c|}{ ( } \\
\hline RP1 & This website/provider has a good reputation & .844 \\
\hline RP2 & $\begin{array}{l}\text { This website/provider has a good reputation compared to other rival } \\
\text { websites }\end{array}$ & .847 \\
\hline RP3 & This website/provider has a reputation for offering good services & .899 \\
\hline RP4 & $\begin{array}{l}\text { This website/provider has a reputation for being fair in its } \\
\text { relationship with its users }\end{array}$ & .860 \\
\hline \multicolumn{3}{|c|}{ Customer Loyalty } \\
\hline LOY1 & My preference for this website would not willingly change & .796 \\
\hline LOY2 & It would be difficult to change my beliefs about this website & .829 \\
\hline LOY3 & $\begin{array}{l}\text { Even if close friends recommended another website, my preference } \\
\text { for this website would not change }\end{array}$ & .842 \\
\hline LOY4 & $\begin{array}{l}\text { I will buy/deal from this website the next time I purchase/need the } \\
\text { banking product/service }\end{array}$ & .742 \\
\hline LOY5 & $\begin{array}{l}\text { I intend to keep purchasing/using the banking products/services } \\
\text { from this website }\end{array}$ & .725 \\
\hline
\end{tabular}


Descriptive Statistics

\section{Characteristics of Respondents}

Table 6 presents descriptive profiles of the sample $(\mathrm{N}=289)$, including two major items in this study: (1) demographic profiles (gender, age group, race, education level, income level, marital status) and (2) Internet banking usage profiles (list of Internet banking used, frequency of usage, last time used, last Internet banking website used). It showed that there were slightly more of male respondents (54\%) than female (46\%). The majority of the respondents belongs to the age group between 26 years old and 30 years old $(61.9 \%)$ and are of Chinese ethnicity (74.4\%). Respondents who possess a bachelor degree or professional certificate are in the majority (70.9\%). Moreover, $40.5 \%$ of the respondents are from the group with incomes between RM3,001 and RM5,000 and more than $67 \%$ of the respondents were single. Furthermore, a majority of the respondents $(76.5 \%)$ is using the Maybank2u.com Internet banking website which was the first Internet banking website to be introduced in Malaysia by Maybank. The most frequently last used Internet banking website was also Maybank2u.com with $60.6 \%$ of last users. Most of the respondents use an Internet banking website more than five times per month (43.4\%) and $77.5 \%$ of the respondents had used an Internet banking website either a week ago or less.

Table 6: Profiles of the Sample

\begin{tabular}{|l|l|l|}
\hline Classification & Frequency & $\mathbf{\%}$ \\
\hline Demographic Profile \\
\hline Gender & 156 & 54 \\
\hline Male & 133 & 46 \\
\hline Female & \multicolumn{2}{|l|}{} \\
\hline \multicolumn{3}{|l|}{} \\
\hline Age Group & 3 & 1 \\
\hline $16-20$ & 24 & 8.3 \\
\hline $21-25$ & 179 & 61.9 \\
\hline $26-30$ & 51 & 17.6 \\
\hline $31-35$ & 25 & 8.7 \\
\hline $36-40$ & & \\
\hline & 7 & 2.4 \\
\hline $41-45$ & \multicolumn{2}{|l}{} \\
\hline
\end{tabular}

\begin{tabular}{|c|c|c|}
\hline Classification & Frequency & $\%$ \\
\hline \multicolumn{3}{|l|}{ Race } \\
\hline Malay & 46 & 15.9 \\
\hline Chinese & 215 & 74.4 \\
\hline Indian & 19 & 6.6 \\
\hline Others & 9 & 3.1 \\
\hline \multicolumn{3}{|l|}{ Marital Status } \\
\hline Single & 195 & 67.5 \\
\hline Married & 92 & 31.8 \\
\hline Divorced & 2 & 0.7 \\
\hline \multicolumn{3}{|l|}{ Education Level } \\
\hline PMR/LCE or Below & 1 & 0.3 \\
\hline Certificate/Diploma & 33 & 11.4 \\
\hline $\begin{array}{l}\text { Degree/Professional } \\
\text { Certificate }\end{array}$ & 205 & 70.9 \\
\hline Postgraduate & 50 & 17.3 \\
\hline \multicolumn{3}{|l|}{ Monthly Income } \\
\hline$<=$ RM1,500 & 15 & 5.2 \\
\hline RM1,501 - RM3,000 & 67 & 23.2 \\
\hline RM3,001 - RM5,000 & 117 & 40.5 \\
\hline RM5,001 - RM7,000 & 32 & 11.1 \\
\hline RM7,001 - RM9,000 & 12 & 4.2 \\
\hline >= RM9,001 & 17 & 5.9 \\
\hline $\begin{array}{l}\text { Unknown } \\
\text { Value) }\end{array}$ & 29 & 10.0 \\
\hline \multicolumn{3}{|l|}{ Usage Profiles } \\
\hline \multicolumn{3}{|c|}{ List of Internet Banking Website Used } \\
\hline Maybank2u.com & 221 & 76.5 \\
\hline CIMB Clicks & 77 & 26.6 \\
\hline $\begin{array}{l}\text { PBeBank.com (Public } \\
\text { Bank) }\end{array}$ & 49 & 16.9 \\
\hline RHB Internet Banking & 28 & 9.7 \\
\hline Hong Leong Online & 19 & 6.6 \\
\hline OCBC Internet Banking & 35 & 12.1 \\
\hline AmOnline (Ambank) & 14 & 4.8 \\
\hline UOB Internet Banking & 12 & 4.2 \\
\hline Citibank Online & 69 & 23.9 \\
\hline $\begin{array}{l}\text { Standard } \quad \text { Chartered } \\
\text { Online }\end{array}$ & 44 & 15.2 \\
\hline Online@HSBC & 54 & 18.7 \\
\hline Others & 7 & 2.4 \\
\hline \multicolumn{3}{|c|}{ Usage Frequency of Internet Banking Website } \\
\hline 1-2 times per month & 79 & 27.3 \\
\hline 3-5 times per month & 85 & 29.4 \\
\hline$>5$ times per month & 125 & 43.3 \\
\hline \multicolumn{3}{|c|}{ Latest Time Usage of Internet Banking Website } \\
\hline 1 weeks ago or lesser & 224 & 77.5 \\
\hline $2-3$ weeks ago & 41 & 14.2 \\
\hline
\end{tabular}




\begin{tabular}{|c|c|c|}
\hline Classification & Frequency & $\%$ \\
\hline 1-3 months ago & 13 & 4.5 \\
\hline More than 3 months ago & 1 & 0.3 \\
\hline More than 6 months ago & 10 & 3.5 \\
\hline \multicolumn{3}{|c|}{ Latest Internet Banking Website Used } \\
\hline Maybank2u.com & 175 & 60.6 \\
\hline CIMB Clicks & 29 & 10.0 \\
\hline $\begin{array}{l}\text { PBeBank.com (Public } \\
\text { Bank) }\end{array}$ & 16 & 5.5 \\
\hline \multicolumn{3}{|c|}{ Latest Internet Banking Website Used } \\
\hline RHB Internet Banking & 8 & 2.8 \\
\hline Hong Leong Online & 2 & 0.7 \\
\hline OCBC Internet Banking & 23 & 8.0 \\
\hline AmOnline (Ambank) & 3 & 1.0 \\
\hline UOB Internet Banking & 3 & 1.0 \\
\hline Citibank Online & 8 & 2.8 \\
\hline $\begin{array}{l}\text { Standard Chartered } \\
\text { Online }\end{array}$ & 13 & 4.5 \\
\hline Online@HSBC & 8 & 2.8 \\
\hline Others & 1 & 0.3 \\
\hline
\end{tabular}

* Note: The sample size $(\mathrm{N})$ is 289

\section{Descriptive Analysis of Research Variables}

Table 7 shows some descriptive results for the research variables used in this study. The table shows minimum, maximum, mean and standard deviation for the research variables of service quality, perceived value, trust, habit, reputation and customer loyalty. The results shown below are the summation of all the items belong to each variable from the seven-point Likert scale. The mean scores of service quality is 5.29 $(=90.24 / 17)$ in a seven-point Likert scale that shows the respondents have slightly positive evaluations of the service quality of Internet banking website. Respondents also had slightly higher perceptions of the value of Internet banking websites as indicated by the average means score of 5.14 for the perceived value variable $(=15.43 / 3)$.

Besides that, the average means score for trust is $5.21(=26.03 / 5)$, for habit it is 5.23 $(=20.90 / 4)$ and for reputation, 5.31 $(=21.23 / 4)$. These scores mean that respondents tend to: trust Internet banking websites, agree that habit does influence their Internet banking choice, as does the Internet banking website/provider's (positive) reputation. Lastly, for the customer loyalty variable, the means score is $4.89(=24.43 / 5)$. Thus, the result suggests that the respondents tend to be only slightly loyal to the Internet banking website, if at all.

Table 7: Descriptive Statistics of Research Variables

\begin{tabular}{|l|l|l|l|l|}
\hline & Min & Max & Mean & $\begin{array}{l}\text { Standard } \\
\text { Deviation }\end{array}$ \\
\hline Service Quality & 62 & 119 & 90.24 & 11.803 \\
\hline Perceived Value & 6 & 21 & 15.43 & 3.212 \\
\hline Trust & 15 & 35 & 26.03 & 4.079 \\
\hline Habit & 13 & 28 & 20.90 & 3.575 \\
\hline Reputation & 12 & 28 & 21.23 & 3.619 \\
\hline Customer Loyalty & 12 & 35 & 24.43 & 4.745 \\
\hline
\end{tabular}

\section{Multiple Regression Analysis}

In order to examine the factors influencing customer loyalty towards Internet banking websites in Malaysia, multiple regression analysis was performed. Table 8 and Table 9 show that the regression coefficient is significant $(F(5,283)=50.95, \mathrm{p}<0.01)$. There is a correlation between the 5 independent variables (reputation, habit, perceived value, trust and service quality) with the dependent variable, customer loyalty $(\mathrm{R}=.069)$. Reputation, habit, perceived value, trust and service quality explain $47 \%$ of the variance in customer loyalty $\left(R^{2}=0.47\right)$ and $46.4 \%$ of the variance of customer loyalty of the population (Adjusted $\mathrm{R}^{2}=0.464$ ). 
Table 8: Multiple Regressions of IVs on DV (Customer Loyalty)

\begin{tabular}{|l|l|l|l|}
\hline $\mathbf{R}$ & $\mathbf{R}^{\mathbf{2}}$ & Adj. $\mathbf{R}^{\mathbf{2}}$ & $\begin{array}{l}\text { Standard Error of } \\
\text { the Estimate }\end{array}$ \\
\hline .68 & .474 & .464 & 3.473 \\
8 & & & \\
\hline
\end{tabular}

Table 9: Significant of IVs on DV (Customer Loyalty)

\begin{tabular}{|l|l|l|l|l|}
\hline & $\begin{array}{l}\text { Sum } \\
\text { of Squares }\end{array}$ & df & F & Sig. \\
\hline $\begin{array}{l}\text { Regressio } \\
\mathrm{n}\end{array}$ & 3072.10 & 5 & 50.95 & .000 \\
\hline Residual & 3412.68 & 283 & & \\
\hline Total & 6484.79 & 288 & & \\
\hline
\end{tabular}

Table 10 shows that trust, habit and reputation correlate positively and significantly with customer loyalty, but not service quality and perceived value are not so correlated. Trust was found as a significant, positive predictor of customer loyalty $(\beta=0.28, p<0.01)$. Habit $(\beta=0.25$, $\mathrm{p}<0.01)$ and reputation $(\beta=0.35, \mathrm{p}<0.01)$ also is a significant, positive predictor on customer loyalty. However, service quality $(\beta=-0.07, p>0.01)$ and perceived value $(\beta$ $=0.04, \mathrm{p}>0.05$ ) was found not significantly predicting customer loyalty. Besides that, findings show that reputation coefficients $(\beta$ $=0.35)$ is the highest, follow by trust $(\beta=$ $0.28)$ and habit $(\beta=0.25)$. This indicates that reputation is more predictive of customer loyalty than trust and habit.

Table 10: Significant of IVs on DV (Customer Loyalty)

\begin{tabular}{|l|l|l|l|l|l|}
\hline & \multicolumn{2}{|l|}{$\begin{array}{l}\text { Unstandardized } \\
\text { Coefficients }\end{array}$} & $\begin{array}{l}\text { Unstandardize } \\
\text { d Coefficients }\end{array}$ & & \\
\hline & B & Std. Error & Beta & t & Sig. \\
\hline (Constant) & 1.144 & 1.675 & & .683 & .495 \\
\hline Service Quality & -.029 & .027 & -.073 & -1.074 & .284 \\
\hline Perceived Value & .064 & .083 & .043 & .773 & .440 \\
\hline Trust & .325 & .070 & .280 & 4.641 & .000 \\
\hline Habit & .325 & .069 & .245 & 4.680 & .000 \\
\hline Reputation & .456 & .082 & .348 & 5.539 & .000 \\
\hline
\end{tabular}

Based on the findings, service quality and perceived value are not predictors of customer loyalty towards Internet banking websites in Malaysia, thus, $\mathbf{H 1}$ and $\mathbf{H 2}$ are rejected. Rejection of $\mathrm{H} 1$ is supported by | past studies by Kouthouris and Alexandris (2005) in the sports tourism industry, Manhaimer (2007) in the retail industry and Cristobal et al. (2007) in an online usage context where higher level of service quality apparently do not foster customer loyalty. Furthermore, findings by Omar et al. (2007) on perceived value do not appear to foster customer loyalty in a retail market context, and by Petrick and Backman (2002) on perceived value not being the prediction of loyalty in the golf traveller market, support the rejection of $\mathrm{H} 2$.

On the other hand, trust, habit and reputation have a significant, positive influence on customer loyalty. Thus; $\mathbf{H 3}, \mathbf{H 4}$ and $\mathbf{H 5}$ are supported in this study, with Beta values of 0.28 for Trust, 0.25 for Habit and 0.35 for Reputation against Customer Loyalty. The empirical findings of this study are in line with the evidence offered by Lin and Wang (2006) and Casalo et al. (2008). Major findings from these two studies have indicated that trust, habit and reputation play an important role in building customer loyalty in an Internet banking website context in Malaysia. 
Additionally, when compared, independent variables of trust, habit and reputation have a highly significant, positive influence on customer loyalty towards Internet banking website. These are followed in significance by trust and habit accordingly. Although trust and habit are still necessary for customer loyalty to Internet banking websites, the results have shown that reputation has becoming an essential factor for ensuring customer loyalty in Malaysia.

\section{Conclusion}

\section{Research Conclusion and Implications}

The analysis finds that hypotheses three to five are supported, while hypotheses one and two are rejected at the significance level of 0.01. Among the five independent variables, reputation is the best predictor of customer loyalty towards an Internet banking website. Results of the hypotheses testing are summarized in Table 11.

Table 11: Summary of Hypotheses Testing

\begin{tabular}{|c|c|c|c|c|}
\hline \multicolumn{2}{|c|}{ Hypothesis } & Coefficien & Result & Supported Literatures \\
\hline H1 & $\begin{array}{l}\text { Service quality has a } \\
\text { positive influence on } \\
\text { customer loyalty towards } \\
\text { Internet banking website }\end{array}$ & -.073 & $\begin{array}{l}\text { Not } \\
\text { Supported }\end{array}$ & $\begin{array}{l}\text { Manhaimer (2007); } \\
\text { Cristobal et al. (2007); } \\
\text { Kouthouris \& Alexandris } \\
(2005)\end{array}$ \\
\hline $\mathrm{H} 2$ & $\begin{array}{l}\text { Perceived value has a } \\
\text { positive influence on } \\
\text { customer loyalty towards } \\
\text { Internet banking website }\end{array}$ & .043 & $\begin{array}{l}\text { Not } \\
\text { Supported }\end{array}$ & $\begin{array}{l}\text { Omar et al. (2007); } \\
\text { Petrick \& Backman (2002) }\end{array}$ \\
\hline H3 & $\begin{array}{lr}\begin{array}{l}\text { Trust has a } \\
\text { influence on }\end{array} & \text { positive } \\
\text { customer } \\
\text { loyalty towards } \\
\text { banking website }\end{array}$ & .280 & Supported & $\begin{array}{l}\text { Cyr et al. (2007); } \\
\text { Floh \& Treiblmaier (2006); } \\
\text { Lin \& Wang (2006); } \\
\text { Ribbink et al. (2004); }\end{array}$ \\
\hline $\mathrm{H} 4$ & $\begin{array}{lr}\begin{array}{l}\text { Habit has a positive } \\
\text { influence on } \\
\text { loyalty towards } \\
\text { lnternet } \\
\text { banking website }\end{array} \\
\end{array}$ & .245 & Supported & $\begin{array}{l}\text { Lin \& Wang (2006); } \\
\text { Liao et al (2006); } \\
\text { Gefen (2003); }\end{array}$ \\
\hline H5 & $\begin{array}{l}\text { Reputation has a positive } \\
\text { influence on customer } \\
\text { loyalty towards Internet } \\
\text { banking website }\end{array}$ & .348 & Supported & $\begin{array}{l}\text { Casalo et al. (2008); } \\
\text { Goode \& Harris (2007); } \\
\text { Andreassen \& Lindestad } \\
\text { (1998); } \\
\text { Robertson (1993); }\end{array}$ \\
\hline
\end{tabular}

All these results lead to the achievement of the stated research questions and consequently lead to a number of conclusions and managerial implications which are as follows:

Firstly, service quality and perceived value is not a predictor of customer loyalty towards Internet banking websites in Malaysia; customers tend not to be loyal although the Internet banking providers provide high quality services and have gained high customer perceived value. Although it is not consistent with most of the previous studies in the Western countries, there are few publications that support the negative findings which were produced by this study, as shown in Table 11. From a managerial perspective, Internet banking providers in Malaysia heed to 
realize that providing good Internet banking services alone does not guarantee customer retention. Service quality is not a major factor to differentiate competitive offerings. Based on comments by some of the respondents, good service quality is a must and is expected to be offered by each Internet banking provider in the first place. This perception will result in the bonding relationship between service quality and loyalty is not so strong in Malaysia. However, for the Internet banking provider, they should not totally ignore these two factors as they are the fundamental attributes to be incorporated into Internet banking services to strategize the Internet banking business and increase user retention. It should be noted that service quality and perceived value are fundamental attributes for retention the users of the Internet banking that Internet banking providers must facilitate. However for customer retention strategy, Internet banking providers in Malaysia should look for other factors that can help to create loyalty in order to sustain competitive advantage in long run.

Secondly, consumers who place a high degree of trust in an Internet banking provider are more likely to become a loyal customer to that particular Internet banking website. Customers who do not trust their Internet banking provider will not use and remain loyal to that Internet banking website. This finding is consistent with prior studies as shown in Table 11. From a managerial standpoint, Internet banking website providers should create a trust relationship with the customers by being honest, sincere and keeping their promises to their customers. Moreover, it is important to emphasize on customers' welfare. The ability to meet customer needs and consistency in delivering services can also create trust in customer towards the Internet banking website provider. In conclusion, Internet banking website providers must try to establish an image which includes integrity, benevolence, competence and predictability in order to keep their customers loyal.

Thirdly, consumer habit is contributing towards loyalty to Internet banking websites in Malaysia. Customers that are used to a particular Internet banking website are unlikely to switch to another site. This is due to the fact that when they switch to another Internet banking website, they have to learn how to use the new site, which means a high switching cost. Therefore, customers will tend to stay loyal to the current Internet banking website, even though superior Internet banking websites are available. As for the managerial implications, customer loyalty can be enhanced by developing a habit among particular bank consumers to use the bank Internet banking website. As repeated use of Internet banking website increases, the habit of using it is developed within the customer. In order to encourage customers to repeatedly use the same Internet banking website, Internet banking website providers should attract customers to their Internet banking website through promotions, contests and coupons. Once customers begin using the website and becoming familiar with it, they may continue of using it if it has become a habit. This will reduce switching behavior to the rival websites and consequently build customer loyalty.

Finally, the reputation of the Internet banking website or provider has influence on customer loyalty towards Internet banking website. In fact, reputation is the most important factor in Malaysia in retaining customer Internet banking website use, with a greater importance than both trust and habit factors. From a managerial standpoint it is important that Internet banking website providers consider reputation as the most critical factor in encouraging loyalty among Malaysian customers towards their Internet banking websites. Continuous effort to build, increase or maintain the website or provider reputation is a must to ensure customer loyalty. This can be done via campaigns or advertising highlighting the positive aspects of both website and provider. Besides that, Internet banking website providers can also increase their reputation by gathering reputable awards such as brand awards. For example, Maybank was awarded "Best Brands Banking Online" in "The Brand Laureate Awards 2008" and "Reader's Digest Trusted Brands - Bank - Gold Award” in 2008. 


\section{Limitations and Recommendations}

Despite being able to demonstrate the relationship between the independent and dependent variables, this study is subject to some limitations. A major limitation is that the results of this study are based on analysis using cross-sectional data due to the time and cost constraint. Therefore, the effects between research variables in the research model cannot be examined thoroughly. A longitudinal study approach is suggested for future research projects.

Secondly, the sample could not generalize of the actual population of Malaysia; the study was limited to Klang Valley using a convenience sampling method where the sample consisted mainly of postgraduate students and white-collar workers that limit the generalization of this study.

In addition, the current study did not include all possible variables which affect customer loyalty towards Internet banking websites. The model serves as a basic overview of the loyalty concept that emphasizes the direct effect of the variables on customer loyalty. It needs to be further enhanced with other possible independent variables which significantly influence customer loyalty. Therefore, for future research, the model should be enhanced by searching for additional variables that can improve the ability accurately to predict customer loyalty towards Internet banking websites in Malaysia. Such additional variables that should be considered may include mediator variables (ie customer satisfaction) or moderator variables (ie customer characteristics and customer involvement).

\section{References}

Aarts, H., Verplanken, B. and van Knippenberg, A. (1998), 'Predicting Behavior from Actions in the Past: Repeated Decision Making or a Matter of Habit?', Journal of Applied Social Psychology, 28(15), 1355-1374.

Anderson, E.W. and Sullivan, M.W. (1993), 'The Antecedents and Consequences of Customer Satisfaction for Firms', Mark Sci, 12(2), 125.
Anderson, R.E. and Srinivasan, S.S. (2003), 'E-satisfaction and E-loyalty: A Contingency Framework', Psychology \& Marketing, 20(2), 123-138.

Andreassen, T. W. and Lindestad, B. (1998), 'The Effect of Corporate Image in the Formation of Customer Loyalty', Journal of Service Research, 1( 1), 82-92.

Arndt, J. (1967), Word of Mouth Advertising: A Review of the Literature, Advertising Research Foundation, NY

Ayny (2008), 'Malaysia to see further increase in online banking adoption' [Online], [Retrieved February 18, 2009], www.ecommercejournal.com $/$ news?page $=727$

Bagozzi, R. P. (1994), Structural equation model in marketing research, Oxford: Blackwell Publishers.

Bamberg, S., Ajzen, I. and Schmidt, P. (2003), 'Choice of travel mode in the theory of planned behavior: The roles of past behavior, habit, and reasoned action', Basic and Applied Social Psychology, 25(3), 175188.

Bansal, H., Irving, G. and Taylor, S. (2003), 'Three Component Model of Customer Commitment to Service Providers', Journal of the Academy of Marketing Science.

Beatty, S.E. and Smith, S.M. (1987), 'External search effort: an investigation across several product categories', Journal of Consumer Research, 14(1), 83-95.

Bernama (2002), More HSBC Customers to Use E-Banking Facility, New Strait Times.

Boulding, W., Kalra, A., Staelin, R. and Zeithaml, V. (1993), 'A Dynamic Process Model of Service Quality', Journal of Marketing Research, 7-27.

Casalo, L., Flavian, C, Guinaliu, M. (2008), 'The Role of Perceived Usability, Reputation, Satisfaction and Consumer Familiarity on the Website Loyalty Formation Process', Computers in Human Behavior, 24(2), 325345. 
Chen, Z. and Dubinsky, A.J. (2003), 'A Conceptual Model of Perceived Customer Value in E-Commerce: A Preliminary Investigation', Psychology and Marketing, 20(4), 323-347.

Chiou, J.S. (2004), 'The antecedents of consumers' loyalty toward Internet service providers', Information \& Management, 41(6), 685-695.

Coakes, S.J. and Steed, L. (2007), SPSS 14.0 for Windows: Analysis without Anguish, Australia: John Wiley \& Sons Ltd.

Corbitt, B.J., Thanasankit, T. and Yi, H. (2003), 'Trust and e-commerce: a study of consumer perceptions', Electronic Commerce Research \& Applications, 2(3), 203-15.

Cristobal, E., Flavian, C. and Guinaliu, M. (2007), 'Perceived E-Service Quality (PeSQ): Measurement Validation and Effects on Consumer Satisfaction and Web Site Loyalty', Managing Service Quality, 17(3), 317-340.

Cronin, J.J. and Taylor, S.A. (1992), 'Measuring service quality: a reexamination and extention', J Mark, 56, 55-68.

Crosby, L A., Evans. K. R, and Cowles, D. (1990), 'Relationship Quality in Services Selling: An Interpersonal Influence Perspective', Journal of Marketing, 54(7), 68-81.

Cyr, D., Hassanein, K., Head, M. and Ivanov, A. (2007), 'The Role of Social Presence in Establishing Loyalty in e-Service Environments', Interacting with Computers, 19(1), 43-56.

Dali, M.M (2008), 'Urban Development and the Social Construction of the Metropolitan Klang Valley', [Online], [Retrieved February 18 , 2009], www.economicdevelopment.org.nz/mdpite ms/presentations/

Dean, A.M. (2002), 'Service Quality in Call Centres: Implications for Customer Loyalty', Managing Service Quality, 12(6), 414-423.

Dodds, W.B., Monroe, K.B. and Grewal, D. (1991), 'Effects of price, brand, and store information on buyers product evaluations', Journal of Marketing Research, 28(3), 307319.

Doney, P. and Cannon, J. (1997), 'An Examination of the Nature of Trust in the Buyer-Seller Relationship', Journal of Marketing, 61(2), 35-51.

Eastlick, M. and Feinberg, R. (1999), 'Shopping motives for mail catalogue shopping', Journal of Business Research, 45, 281-90

Featherman, M. and Pavlou, P. (2002), 'Predicting E-Services Adoption: A Perceived Risk Facet', Eighth Americas Conference on Information Systems, 10341046.

Finn, A. and Kayande, U. (1997), 'Reliability Assessment and Optimization of Marketing Measurement', Journal of Marketing Research, 34(2), 262-275.

Flavian, C., Guinaliu, M. and Gurrea, R. (2006), 'The Role Played by Perceived Usability, Satisfaction and Consumer Trust on Web Site Loyalty', Information \& Management: The International Journal of Information Systems Applications, 43(1), 114.

Floh, A. and Treiblmaier, H. (2006), 'What Keeps the E-Banking Customer Loyal? A Multigroup Analysis of the Moderating Role of Consumer Characteristics on E-Loyalty in the Financial Service Industry', Journal of Electronic Commerce Research, 7(2), 97-110.

Ganesan, S. (1994), 'Determinants of LongTerm Orientation in Buyer-Seller Relationships", Journal of Marketing, 58(2), pp. 1-19.

Gefen, D. (2000), 'E-Commerce: The Role of Familiarity and Trust', Qmega, 28(6), 725737.

Gefen, D. (2002), 'Nurturing Clients' Trust to Encourage Engagement Success During the Customization of ERP Systems', Qmega, 30(4), 287-299.

Gefen, D. (2003), 'TAM or Just Plain Habit: A Look at Experienced Online Shoppers', Journal of End User Computing, 15(3), 1-13. 
Gefen, D., Karahanna, E. and Straub, D.W. (2003), 'Trust and TAM in Online Shopping: An Integrated Model', MIS Quarterly, 27(1), 51-90.

Gefen, D. and Silver, M. (1999), 'Lessons Learned from the Successful Adoption of an ERP System', Proceedings of the Proceedings of the 5th International Conference of the Decision Sciences Institute. Athens, Greece, 1054-1057.

Gremler, D.D., Gwinner, K.P. and Brown, S.W. (2001), 'Generating Positive Word-ofMouth Communication through CustomerEmployee Relationships', International Journal of Service Industry Management, 12(1), 44-59.

Grewal, D., Monroe, K.B. and Krishnan, R. (1998), 'The Effects of Price Comparison Advertising on Buyers' Perceptions of Acquisition Value, Transaction Value, and Behavioral Intentions', Journal of Marketing, 62(2), 46-59.

Goode, M.M.H. and Harris. L.C. (2007), 'Online Behavioural Intentions: An Empirical Investigation of Antecedents and Moderators', European Journal of Marketing, 41(5/6), 512-536.

Hair, J.F., Anderson, R.E., Tatham, R.L., Black, W.C. (1998), Multivariate Data Analysis with Readings, Upper Saddle River, NJ: PrenticeHall.

Harrison-Walker L.J. (2001), 'The Measurement of Word-of-Mouth Communication and an Investigation of Service Quality and Customer Commitment as Potential Antecedents", Journal of Service Research, 4, 60-75.

Hosmer. L, T. (1995), 'Trust: the Connecting Link Between Organizational Theory and Philosophical Ethics', Academy of Management Review, 20(2), 379-403.

Hsu, C. (2007), The Relationship among Service Quality, Perceived Value, Customer Satisfaction and Behavioral Intentions: An Empirical Study of Online Shopping, MBA Thesis, National Cheng Kung University.
Internet Banking Info [Online], [Retrieved February 6, 2009], http://www.bankinginfo.com.my

Jarvenpaa, S.L. and Tractinsky, N. (1999), 'Consumer Trust in an Internet Store: A Cross-Cultural Validation', Journal of Computer Mediated Communication, 5(2), 135.

Jarvenpaa. S. L., Tractinsky. N. and Vitale, M. (2000), 'Consumer Trust in an Internet Store', Information Technology and Management, 1, 45-71.

Lee, M.K.O. and Turban, E. (2001), 'A Trust Model for Consumer Internet Shopping', International Journal of Electronic Commerce, 6(1), 75-91.

Liao, C., Palvia, P. and Lin, H. (2006), 'The Roles of Habit and Web Site Quality in ECommerce', International Journal of Information Management, 26(6), 469-483.

Lin, H. and Wang, Y. (2006), 'An Examination of the Determinants of Customer Loyalty in Mobile Commerce Contexts', Information \& Management, 43(3), 271-282.

List of Licensed Banking Institutions in Malaysia, [Online], [Retrieved February 4, 2009], http://www.bnm.gov.my

Lynch, P., Kent, R., Srinivasan, S. (2001), 'The Global Internet Shopper: Evidence from Shopping Tasks in Twelve Countries', Journal of Advertising Research, 41, 15-23.

Manhaimer, E. (2007), 'Does the Perceived Quality of the Product Influence the Customer Loyalty', [Online], [Retrieved February, 12, 2009], http://ezinearticles.com/?Does-thePerceived-Quality-of-the-Product-Influencethe-Customer-Loyalty\&id=433624)

Mayer. R, C., Davis. J. H. and Schoorman. F. D. (1995), 'An Integration Model of Organizational Trust', Academy of Management Review, 20(3), 709-734.

Mayer, R.C. and Davis, J.H. (1999), 'The Effect of the Performance Appraisal System on Trust in Management: A Field QuasiExperiment', Journal of Applied Psychology, 84(1), 123-136. 
McKnight, D. H., Cummings, L. L. and Chervany, N. L. (1998), 'Initial Trust Formation in New Organizational Relationships', Academy of Management Review, 20(3), 472-490.

Moorman, C., Zaltman, G. and Deshpande, R. (1992), 'Relationships between Providers and Users of Marketing Research: The Dynamic of Trust within and between Organisations', Journal of Market Research, 314-329

Oliver, R.L. (1999), 'Whence customer loyalty?', Journal of Marketing, 63(4), 33-44.

Omar, N.A., Musa, R. and Nazri, M.A. (2007), 'Program Perceived Value and Program Satisfaction Influences on Store Loyalty', International Journal of Business, 9(3), [Online], [Retrieved February 12, 2009], http://www.gamaijb.mmugm.ac.id/

Ouellette, J. A., \& Wood, W. (1998), 'Habit and Intention in Everyday Life: The Multiple Processes by Which Past Behavior Predicts Future Behavior', Psychological Bulletin, 124(1), 54-74.

Pallant, J. (2001), SPSS Survival Manual, Chicago: Open University Press.

Parasuraman, A. (1997), 'Reflections on Gaining Competitive Advantage through Customer Value', Journal of the Academy of Marketing Science, 25(2), 154-161

Parasuraman, A. and Grewal, D. (2000), 'The Impact of Technology on the Quality-ValueLoyalty Chain: A Research Agenda', Journal of the Academy of Marketing Science, 28(1), 168-174.

Parasuraman, A., Zeithaml, V.A. and Malhotra, A. (2005), 'E-S-Qual: A MultipleItem Scale for Assessing Electronic Service Quality', Journal of Service Research, 7(3), 213-233.

Petrick, J.F. and Backman, S.J. (2002), 'An Examination of the Construct of Perceived Value for the Prediction of Golf Travelers' Intentions to Revisit', Journal of Travel Research, 41(1), 38-45

Ranaweera, C. and Neely, N. (2003), 'Some Moderating Effects on the Service QualityCustomer Retention Link', International
Journal of Operations and Production Management, 23(2), 230-248.

Reichheld, F.F., Markey, R.G. Jr and Hopton, C. (2000), 'E-Customer Loyalty - Applying the Traditional Rules of Business for Online Success', European Business Journal, 12(4), 173-179

Reichheld, F.F. and Schefter, P. (2000), 'ELoyalty: Your Secret Weapon on the Web', Harvard Business Review, 78(4), 105-113.

Reinartz, W.J. and Kumar, V. (2002), 'The Mismanagement of Customer Loyalty', Harvard Business Review, 80(7), 86-94.

Rempel, J. K., Holmes, J, G. and Zanna. M. P. (1985), 'Trust in Close Relationships', Journal of Personality and Social Psychology, 49(1), 95-112.

Resnick, P., \& Zeckhauser, R. (2002), 'Trust among strangers in Internet transactions: Empirical analysis of eBay's Reputation System', Advances in Applied Microeconomics, 11, 127-157.

Ribbink, D., van Riel, A.C.R., Liljander, V. and Streukens, S. (2004), 'Comfort Your Online Customer: Quality, Trust and Loyalty on the Internet', Managing Service Quality, 14(6), 446-456

Robertson, T. S. (1993), 'How to Reduce Market Penetration Cycle Times', Sloan Management Review, 35(1), 87-96.

Ruyter, K. and Wetzels, M. (1998), 'On the Relationship between Perceived Service Quality, Service Loyalty and Switching Costs', International Journal of Service Industry Management, 9(5), 436-453.

Santos, J. (2003), 'E-Service Quality: A Model of Virtual Service Quality Dimensions', Management Service Quality, 13(3), 233246.

Sanzo, M. J., Santos, M. L., Vazquez, R., \& Alvarez, L. I. (2003), 'The Effect of Market Orientation on Buyer-Seller Relationship Satisfaction', Industrial Marketing Management, 32(4), 327-345. 
Shapiro, C. (1982), 'Consumer Information, Product Quality, and Seller Reputation', The Bell Journal of Economics, 13, 20-35.

Slater, S.F. (1997), 'Developing a Customer Value-Based Theory of the Firm', Journal of the Academy of Marketing Science, 25(2), 162-167.

Srinivasan, S.S., Anderson, R.E. and Ponnavolu, K. (2002), 'Customer Loyalty in E-Commerce: An Exploration of Its Antecedents and Consequences', Journal of Retailing, 78(1), 41-51.

Standifird, S.S., Weinstein, M. and Meyer, A.D. (1999), 'Establishing Reputation on the Warsaw Stock Exchange: International Brokers as Legitimating Agents', Academy of Management Proceedings, Chicago, IL.

Trafimow, D. (2000), 'Habit as Both a Direct Cause of Intention to Use a Condom and as a Moderator of the Attitude-Intention and Subjective Norm-Intention Relations', Psychology and Health, 15(3), 383-393.

Triandis, H. C. (1971). Attitude and Attitude Change. New York, NY: Wiley.

Turban, E., King, D., Lee, J. and Viehland, D. (2004), Electronic Commerce 2004: A Managerial Perspective, Upper Saddle River: Prentice Hall.

Vatanasombut, B., Stylianou, A.C. and Igbaria, M. (2004), 'How to Retain Online Customers', Communications of the ACM, 47(6), 65-69.

Verplanken, B., Aarts, H., van Knippenberg, A., and Moonen, A. (1998), 'Habit versus Planned Behavior: A Field Experiment', British Journal of Social Psychology, 37(1), 111-128.
Voss, G.B., Parasuraman, A. and Grewal, D. (1998), 'The Roles of Price, Performance, and Expectations in Determining Satisfaction in Service Exchanges', Journal of Marketing, 62(4), 46-61.

Wolfinbarger, M. and Gilly, M.C. (2002), 'COMQ: Dimensionalizing, Measuring and Predicting Quality of the E-Tailing Experience', MSI working paper series, no. 02-100, Marketing Science Institute, Boston, MA.

Woodruff, R.B. (1997), 'Customer Value: The Next Source for Competitive Advantage', Journal of the Academy of Marketing Science, 25(2), 139-153.

Yu, W. (2002), Maybank Targets Consumers, New Strait Times.

Zahorik, A.J and Rust, RT, ed. (1992), Modeling the Impact of Service Quality on Profitability: A Review, JAI Press.

Zeithaml, V.A., Berry, L.L and Parasuraman, A. (1996), 'The Behavioral Consequences of Service Quality', Journal of Marketing, 60(2), 31-46.

Zeithaml, V.A., Parasuraman, A. and Malhotra, A. (2002), 'Service Quality Delivery through Web Sites: A Critical Review of Extant Knowledge', Journal of the Academy of Marketing Science, 30(4), 362375.

Zeithaml, V.A., Parasuraman, A. and Malhotra, A. (2001), 'A Conceptual Framework for Understanding E-Service Quality: Implications for Future Research and Managerial Practice', working paper, report no. 00-115, Marketing Science Institute, Cambridge, MA 